\title{
LIPID FORMATION AND $\gamma$-LINOLENIC ACID PRODUCTION BY MUCOR CIRCINELLOIDES AND RHIZOPUS SP., GROWN ON VEGETABLE OIL
}

\author{
Sâmia M. Tauk-Tornisielo ${ }^{1}$; Luciana S. Arasato ${ }^{1}$; Alex F. de Almeida ${ }^{1}$ José S. Govone $^{2}$; Eleni N. Malagutti ${ }^{1}$ \\ ${ }^{1}$ Centro de Estudos Ambientais, Universidade Estadual Paulista, Rio Claro, SP, Brasil; ${ }^{2}$ Departamento de Estatísticas, \\ Universidade Estadual Paulista, Rio Claro, SP, Brasil.
}

Submitted: October 22, 2007; Returned to authors for corrections: December 06, 2007; Approved: March 30, 2009.

\begin{abstract}
The fungi strains were tested in Bioscreen automated system to select the best nutritional source. Following, shaking submserse cultures were studied in media containing sole carbon or nitrogen source. The growth of these strains improved in media containing vegetable oil, with high concentration of lipids. The high concentration of $\gamma$-linolenic acid was obtained with M. circinelloides in culture containing sesame oil.
\end{abstract}

Key words: automated system, vegetable oils, zigomycetes, $\gamma$-linolenic acid, liquid culture

Essential fatty acids, as $\gamma$-linolenic acid (GLA), are an important precursor of prostaglandin, and is also essential for patients who suffer from diabetes, cancer, aging, even of rheumatic origin; dilate veins and lower blood pressure; reduce cholesterol levels, inhibiting the formation of thromboses and aggregation of platelets $(7,8,17)$. They are called polyunsaturated because they have double bonds in the carbon chain (13). These fatty acids are not synthesized by humans, and must therefore be consumed in the daily diet. GLA occurs in human breast milk and in the vegetable seeds, algae (7) and Mucorales fungal order $(2,4,9,11,22)$. The fungal strains Rhizopus $\mathrm{sp}$. is a producer of GLA, and it is known that some species of Rhizopus sp. can be used to brew fermented glutinous rice, which is a popular oriental brewed food in China (12).

To optimize the production of fatty acids by fungi, various studies have been conducted on the effects of carbon- and nitrogen sources, initial $\mathrm{pH}$ of the culture medium, $\mathrm{C} / \mathrm{N}$ ratio, temperature, and their respective effects on the production of cells and fatty acids $(3,5,6,10,20,21,23,24,26,27)$. This paper deals with the effects of nitrogen and carbon sources for fungal growth, lipid, GLA and arachidonic acid (AA) contents, with an emphasis on vegetable oil as substrate for the culture of Rhizopus sp and Mucor circinelloides. These strains isolated from the soil (0-15 cm deep) in the cerrado vegetation of Corumbataí city, state of São Paulo, and stored at $4^{\circ} \mathrm{C}$ in malt extract agar (Merck). Concentration of $10^{6}$ to $10^{7}$ spores. $\mathrm{mL}^{-1}$ was used as inocula in this study, in a $0.85 \% \mathrm{NaCl}$ solution.

Cultivation in an automated Bioscreen C system (Labsystems Helsinki, Finland), were carried out using $360 \mu \mathrm{L}$ of culture medium with water and 1 - $4 \%$ sole carbon source [malt extract, fructose, galactose, glucose, glycerol, lactose, maltose, mannitol, sorbitol, sucrose, or xylose (Difco)] and/or 1 - 4\% single nitrogen source [ammonium sulfate, peptone, potassium nitrate (Merck) or yeast extract (Himedia)]. In culture media with a sole nitrogen source, $2 \%$ glucose was used as the carbon source. Fourteen microliters of spore solution were inoculated. Four repetitions were carried out using four control tubes without inoculum. The cultivations were maintained at $25^{\circ} \mathrm{C}$ with shaken for 60 seconds before each measurement. Optical density of the cell suspensions was measured automatically at $\lambda 540 \mathrm{~nm}$ at regular intervals of 2 hours, for 4 days. The data were analyzed using spreadsheet software (Excel 97) and the averages of the quadruplicates calculated for each type of culture medium to generate the growth curves for each strain studied.

The submerged cultivation were carried out in $250 \mathrm{~mL}$ Erlenmeyer flasks with $50 \mathrm{~mL}$ of medium containing 1 - $4 \%$ oils (palm, canola, soybean oil that had been used for frying, sesame, or sunflower) or 1 - $4 \%$ carbohydrates (galactose, maltose, malt extract, sorbitol) and $1 \%$ yeast extract as nitrogen source. Each

*Corresponding Author. Mailing address: Centro de Estudos Ambientais, UNESP, Campus Rio Claro, SP, 13506-900. E-mail: seb@rc.unesp.br 
flask was inoculated with $1 \mathrm{ml}$ of freshly prepared spore suspension. For M. circinelloides, malt extract was also used replacing maltose in the medium. The cultures were agitated continuously for 72 hours at $150 \mathrm{rpm}$, at $25^{\circ} \mathrm{C}$ and allowed to stand for 48 hours without agitation at $12^{\circ} \mathrm{C}$. The biomass produced was separated using vacuum filtration in No. 1 Whatman filter paper. The wet biomass was placed in preweighed beakers at $105^{\circ} \mathrm{C}$ for $48 \mathrm{~h}$ to determine the dry weight. After part of the resulting biomass was set aside for later extraction of the fatty acids; it was dried by storage for 5 days in an oven at $55^{\circ} \mathrm{C}$.

Approximately 100mg of mycelia were used to extraction of lipid using chloroform:methanol:water $(2: 1: 0,8)$ and the solvent removed in a nitrogen atmosphere. The procedure was adapted from Kennedy et al. (15). Fatty acids methyl esters (FAME) were prepared using $2 \mathrm{M}$ sodium methanol hydroxide and added anhydrous calcium chloride, followed by centrifugation at 3,990x $\mathrm{g}$ for 8 min in centrifuge Jouan model GR20 22 20. The FAME were analysed by gas chromatography (Finnigan-Tremetrics chromatograph, model 9001, San Jose, CA., USA), in a free fatty acid polymerase (FFAP) column of 30-m mega bore, with $1-\mu \mathrm{m}$ film, with hydrogen flow in the flame, $20 \mathrm{~mL} \mathrm{~min}^{-1}$; nitrogen flow, $25 \mathrm{~mL} \mathrm{~min}^{-1}$; constant $4 \mathrm{psi}$; temperature of the injector at $210^{\circ} \mathrm{C}$; temperature of the detector ionization flame (FID) at $250^{\circ} \mathrm{C} ; 50^{\circ} \mathrm{C}$ to $220^{\circ} \mathrm{C}$ column temperature. The FAME were identified by comparing with their known methyl ester patterns.

A total of 160 growth curves for carbon sources and 64 growth curves for nitrogen sources were obtained. Fungal cultures grew best in media containing yeast extract $4 \%$ plus galactose (2\%) during 60 hours. Probably microorganisms are not able to synthesise components of the yeast extract such as vitamins that are necessary to its growth. The occurrence of the initiation of the log and stationary phases varied according to the strain studied and the carbon sources utilized.

Variable results are related with relation to the best carbon source for the microorganisms of the genera Mucor or Rhizopus. Glucose is the greater inducing the growth of filamentous fungi, but can be replaced for others carbon sources as potato dextrose broth, starch or hydrolyzed starch or to vary even within the intraspecific level $(16,25)$.

Although the data are presented by optical density (OD), and not by number of cells, these values have a strong similarity between them with relation to the increase or decrease tendency (14). The methodology in an automated system like Bioscreen $\mathrm{C}$ proved to be appropriate for the liquid medium cultures, being rapid and automated, and providing good prior indication of the optimal environmental factors for growth of the filamentous fungi (26). Bioscreen $\mathrm{C}$ has been also used for other authors studying filamentous fungi $(14,18)$. In this study, it was enable to select the best carbon and nitrogen sources.

The cultivation in canola, palm, sesame, soybean (postfrying, usually poured down the kitchen drain) and sunflower oils, there was greater biomass production than in the cultures of media where carbohydrate was used as sole carbon source (Tables 1 and 2). Soybean oil (post-frying) was another option worth evaluating selected with the intention of seeking an alternative way to reuse this oil.

The GLA production was calculated in relation to the amount of total lipids. The strains accumulated around $30.0-54.3 \%$ lipid in their biomass. It was confirmed that the strains were not efficient in the production of arachidonic acid (AA), but they produced relatively large quantities of $\gamma$-linolenic acid (GLA). In the results found here, despite the lower AA production in relation to GLA, the concentration of AA depended of the carbon source added to the culture medium, soybean, sesame, palm oils or malt extract. In literature it was cited that, in $M$ circinelloides cultures, others authors did not observe GLA production $(1,6)$.

In the fungi strain cultures obtained here, the conditions may not have been suitable for the appearance or action of the enzymes dessaturases e enlogases, and consequently, for the formation of AA. Another reason may be that, as inflammation, infection and modulation of the immune system do not occur in fungi, their necessity for AA may be lower. Based on the results obtained, however, it is clear that oils can be employed as a carbon source for microbial lipid production.

The results showed that the cultures of M. circinelloides in vegetable oils (Table 2) were even superior to those obtained with Rhizopus sp, and also in comparison to the cultures of Thamnidium elegans with glucose media, 16.8 - 21.0\% (24). The

Table 1. Biomass (g.L $\mathrm{L}^{-1}$ dried weight), total lipids (\%weight lipids per weight biomass), GLA and AA (\%weight per weight total lipids) in cultures of Rhizopus sp. in media containing vegetable oil or carbohydrate as sole carbon source and yeast extract as sole nitrogen source. Legend: $\mathrm{n} . \mathrm{d}=$ not detected; $\mathrm{pf}=$ postfrying.

\begin{tabular}{|c|c|c|c|c|c|c|c|}
\hline \multirow[t]{2}{*}{$\begin{array}{l}\text { Carbon } \\
\text { source }\end{array}$} & \multirow[t]{2}{*}{$\begin{array}{c}\text { Biomas } \\
\text { - g.L } \text { L }^{-1} \\
\text { dried } \\
\text { weight }\end{array}$} & \multicolumn{2}{|c|}{$\begin{array}{l}\text { Total } \\
\text { lipids }\end{array}$} & \multicolumn{2}{|c|}{ GLA } & \multicolumn{2}{|c|}{ AA } \\
\hline & & $\overline{\% \text { w.w }}$ & g. $\mathrm{L}^{-1}$ & \%w.w & g. $\mathrm{L}^{-1}$ & \%w.w & g. $L^{-1}$ \\
\hline Soybean (pf) & 10.1 & 28.4 & 3.2 & 32.5 & 1.0 & n.d. & n.d. \\
\hline Sesame & 12.0 & 33.3 & 4.4 & 20.3 & 0.9 & 0.4 & 0.0 \\
\hline Canola & 10.0 & 40.6 & 4.5 & 26.9 & 1.2 & n.d. & n.d. \\
\hline Sunflower & 9.1 & 36.0 & 3.6 & 25.0 & 0.9 & n.d. & n.d. \\
\hline Palm & 11.9 & 54.3 & 6.5 & 15.8 & 1.0 & 0.4 & 0.0 \\
\hline Maltose & 9.0 & 3.5 & 0.3 & 56.4 & 0.2 & 0.6 & 0.0 \\
\hline Galactose & 6.8 & 5.1 & 0.4 & 64.1 & 0.3 & 0.3 & 0.0 \\
\hline Sorbitol & 7.7 & 4.4 & 0.4 & 52.1 & 0.2 & n.d. & n.d. \\
\hline
\end{tabular}


Table 2. Biomass (g.L $\mathrm{L}^{-1}$ dried weight), total lipids (\%weight lipids per weight biomass), GLA and AA (\%weight per weight total lipids) in cultures of Mucor circinelloides in media containing vegetable oil or carbohydrate as sole carbon source and yeast extract as sole nitrogen source. Legend: $\mathrm{n} . \mathrm{d}=$ no detected; $\mathrm{pf}=$ post-frying.

\begin{tabular}{|c|c|c|c|c|c|c|c|}
\hline \multirow[t]{2}{*}{$\begin{array}{c}\text { Carbon } \\
\text { source }\end{array}$} & \multirow[t]{2}{*}{$\begin{array}{c}\text { Biomass } \\
\text { - g.L. } \mathrm{L}^{-1} \\
\text { dried } \\
\text { weight }\end{array}$} & \multicolumn{2}{|c|}{$\begin{array}{l}\text { Total } \\
\text { lipids }\end{array}$} & \multicolumn{2}{|c|}{ GLA } & \multicolumn{2}{|c|}{ AA } \\
\hline & & \%w.w & g. $\mathrm{L}^{-1}$ & \%w.w & g. $\mathrm{L}^{-1}$ & \%w.w & g. $\mathrm{L}^{-1}$ \\
\hline Soybean & 9.2 & 42.3 & 3.9 & 47.8 & 2.1 & 0.2 & 0.0 \\
\hline Sesame & 12.9 & 40.0 & 5.7 & 71.5 & 4.1 & 0.6 & 0.0 \\
\hline Canola & 9.6 & 36.6 & 3.9 & 83.5 & 3.3 & 1.3 & 0.0 \\
\hline Sunflower & 10.0 & 30.0 & 3.0 & 60.0 & 1.8 & 1.0 & 0.0 \\
\hline Palm & 14.4 & 5.1 & 0.8 & 0.7 & 0.0 & 0.6 & 0.0 \\
\hline Malt extract & $\mathrm{t} \quad 5.2$ & 4.6 & 0.3 & 18.9 & 0.7 & 0.6 & 0.0 \\
\hline Galactose & 7.0 & 4.0 & 0.3 & 0.7 & 0.0 & 0.0 & 0.0 \\
\hline Sorbitol & 4.8 & 2.0 & 0.1 & 0.0 & 0.0 & n.d. & n.d. \\
\hline
\end{tabular}

total lipid production from $M$. circinelloides was higher than that observed for Mucor rouxii cultivated with starch- or hydrolyzed media (16). The M. circinelloides strain produced $4.1 \mathrm{~g} . \mathrm{L}^{-1}$, 3.3g. $\mathrm{L}^{-1}$, and 2.1 g.. $\mathrm{L}^{-1}$ in culture with sesame, canola or soybean oil as single carbon sources, respectively (Table 2 ). The vegetable oils resulted in greater quantities of $M$. hiemalis biomass, although the same was not true for the levels of GLA production (25).

When M. circinelloides was cultivated with carbohydrates as the sole carbon source, the formation of GLA was observed, but the best GLA yield (83.5\%) occurred when canola oil was used as the sole carbon source (Table 1). The largest concentration of GLA (64.1\%) was verified in the total lipid output of Rhizopus sp biomass produced in culture media containing galactose as the sole carbon source (Table 2). The results with $M$. circinelloides showed an elevated lipid accumulation with high quantities of GLA in biomass obtained with canola- or sesame oil media. The M. circinelloides results observed here had been bigger to those findings for other authors (21). In cultures in medium containing vegetable oils were found higher percentages of lipids in the biomass of strains studied, probably resulting from the direct incorporation of the oil source within the intracellular lipids.

Strains of Metarhizium anisopliae majus did not present sizable differences from variety Anisopliae, but for fatty acids, $\mathrm{C} 18: 1$ and C18:2, oleic- and linoleic acid, respectively, the differences were all highly significant $(\mathrm{p}=1 \%)$ with the highest means being obtained for conidia for fatty acid C18:1 and for myclelia for fatty acid C18:2 (19). Optimization of environmental factors for the growth of fungi isolated from the soil in protected areas is the next objective, seeking for alternatives to minimize the costs of culture media and to obtain products that will be commercially competitive.

In general, the two strains of filamentous fungi isolated from soil under cerrado vegetation can be considered new sources of total lipid and GLA in substrates such as vegetable oils, like canola and palm. For the M. circinelloides strain, sesame oil is recommended as the carbon source for production of GLA. Neither of the two strains showed promising results with respect to the production of AA.

\section{ACKNOWLEDGEMENTS}

We thank FAPESP for the Scientific Initiation scholarship granted to one of the authors, and FUNDUNESP for supporting the research.

\section{RESUMO}

\section{Formação de lipídeos e produção de ácido $\gamma$-linolênico por Mucor circinelloides e Rhizopus sp., em óleos vegetais}

Linhagens de fungos foram testadas em sistema automatizado Bioscreen para selecionar melhor fonte nutricional. Em seguida, foram estudadas culturas submersas em meios contendo uma única fonte de carbono e de nitrogênio. As linhagens contendo alta concentração de lipídeos tiveram melhor crescimento em meio contendo óleos de gergelim ou de dendê. Maior concentração de ácido $\gamma$-linolênico foi obtida com M. circinelloides nas culturas em óleo de gergelim.

Palavras-chave: sistema automatizado de crescimento, óleos vegetais, zigomicetos, ácido $\gamma$-linolênico, ácido araquidônico.

\section{REFERENCES}

1. Almeida, A.F. (2007). Cultivo de Mucor circinelloides em substratos líquido e sólido para produção de ácidos graxos insaturados. Master, Instituto de Biociências, UNESP. 107p.

2. Aggelis, A.; Pina, M.; Graille, J. (1990). Localización de l'acide gamma linolénique dans les mycéliums et dans les spores chez deux mucorales. Oléagineux. 45: 229-32.

3. Aggelis, G. (1996). Two alternative pathways for substrate assimilation by Mucor circinelloides. Folia Microbiol., 41: 254.

4. Aggelis, G.; Komaitis, M.E.; Dimitroulias, G.; Pina, M.; Graille, J. (1991). Possibilité de production d'acide gamma linolénique par culture de Mucor circinelloides CBS 172-27 sur quelques huiles végétales. Oléagin., 46: 208-12.

5. Chen, H.C.; Liu, T.M. (1997). Inoculum effects on the production of $\gamma$-linolenic acid by the shake culture of Cunninghamella echinulata CCRC 31840. Enz. Microb. Technol., 21: 137-42.

6. Conti, E.; Stredansky, M.; Stredanska, S.; Zanetti, F. (2001). $\gamma$ Linolenic acid production by solid-state fermentation of Mucorales strains on cereals. Biores Technol., 76: 283-286. 
7. De, B.K.; Chaudhury, S.; Bhattacharyya, D.K. (1999). Effect of nitrogen sources on $\gamma$-linolenic acid accumulation in Spirulina platensi. JAOCS, 76: 153-156.

8. Dubacq, J.P.; Pham-Quoc, K. (1993). Biotechnology of Spirulina lipids: A source of gamma-linolenic acid. Bull. Inst. Oceanograph., 12: $59-64$

9. Gandhi, S.R.; Weete, J.D. (1991). Production of the polyunsaturated fatty acids arachidonic acid and eicosapentaenoic acid by the fungus Pythium ultimum. J. Gen. Microbiol., 137: 1825-1830.

10. Emelyanova, E.V. (1997). Lipid and $\gamma$-linolenic acid production by Mucor inaquisporus. Proc. Biochem., 32: 173-177.

11. Fukuda, H.; Morikawa, H. (1987). Enhancement of $\gamma$-linolenic acid production by Mucor ambiguous with nonionic surfactants. Appl. Microbiol. Biotechnol., 27: 15-20.

12. Gui-You, L.; Sheng, Y.; Chuan-Chao, D. (2004). Factors affecting $\gamma$ linolenic acid content in fermented glutinous rice brewed by Rhizopus sp. Food Microbiol., 21: 299-304.

13. Horrobin, D.F. (1992). Nutritional and medical importance of gamma-linolenic acid. Prog. Lipid Res., 31: 163-194.

14. Johnston, M.D. (1998). A simple and rapid test for quality control of liquid media, using the bioscreen microbiological growth analyzer. J. Microbiol. Meth., 32: 37-43.

15. Kennedy, M.J.; Reader S.L.; Davies R.J. (1993). Fatty acid production characteristics of fungi with particular emphasis on gamma linolenic acid production. Biotechnol. Bioeng., 42: 625-634.

16. Lindberg, A.-M.; Hansson, L. (1991) Prodouction of gamma-linolenic acid by Mucor rouxii on cheap nitrogen and carbon sources. Appl. Microbiol. Biotechnol., 36: 26-28.

17. Odabasi, Z.; Paetznick, V.L.; Rodríguez, J.R.; Chen, E.; OstroskyZeichener, L. (2004). In Vitro Activity of anidulafungin against selected clinically important mold isolates antimicrobial. Agents Chemother., 48: 1912-1915.

18. Pupin, A.M.; Messias, C.L.; Piedrabuena, A.E. et al. (2000). Total lipids and fatty acids of strains of Metarhizium anisopliae. Braz. J. Microbiol., 31: 121-128.
19. Reinhart, G.A. (1996). Review of omega-3 fatty acids and dietary influences on tissue concentrations. In: Recent advances in canine and feline nutritional research. Wilmington: Orange Frazer press, 235-242.

20. Roux, M.P.; Kock, J.L.F.; Du Preez, J.C.; Botha, A. (1995). The influence of dissolved oxygen tension on the production of cocoa butter equivalents and gamma-linolenic acid by Mucor circinelloides. System. Appl. Microbiol., 18: 329-334.

21. Ruegger, M.J.S.; Tauk-Tornisielo, S.M.; Pastore, G.M. (2002). Isolamento de fungos produtores de ácido $\gamma$-linolênico de solo da Estação Ecológica de Juréia-Itatins, SP. Rev. Ciên. Farm., 23: 4958.

22. Somashekar, D.; Venkteshwarn, G.; Sambaiah, K.; Lokesh, B.R (2002). Effect of culture conditions on lipid and gamma-linolenic acid production by mucoraceous fungi. Proc. Biochem., 00: 1-6.

23. Stredansky, M.; Conti, E.; Stredanska, S.; Zanetti, F. (2000). $\gamma$ linolenic acid production with Thamnidium elegans by solid state fermentation on apple pomace. Biores. Technol., 73: 41-45.

24. Tauk-Tornisielo, S.M.; Vieira, J.M.; Carneiro, M.C.V.S.; Govone, J.S. (2007). Fatty acid production by four strains of Mucor hiemalis grown in plant oil and soluble carbohydrates. Afr. J. Biotechnol., 6 : $1840-1847$.

25. Tauk-Tornisielo, S.M.; Vieira, J.M.; Govone, J.S. (2007). Use of Bioscreen $\mathrm{C}$ for growth of Mucor hiemalis in different carbon and nitrogen sources. Braz. J. Microbiol., 38: 113-117.

26. Torlanova, B.O.; Funtikova, N.S.; Konova, I.V.; Babanova, N.K (1995). Synthesis of the lipid complex containing gamma-linolenic acid and carotenoids by a mucorous fungus under various cultivation conditions. Mikrobiol., 64: 492-496.

27. Vaughn, D.M.; Reinhart, G.A. (1996). Influence dietary fatty acid ratios on tissue eicosanoid production and blood coagulation parameters in dog. In: Recent advances in canine and feline nutritional research - IANS International Nutrition Symposium, 243-255. 